Cipango $\begin{aligned} & \text { Cipango } \\ & \text { Cahiers d'études japonaises }\end{aligned}$

Hors-série | 2008

Autour du Genji monogatari

\title{
Variations sur le chapitre Suma
}

Variations on the chapter Suma

\section{(2) OpenEdition}

1 Journals

Édition électronique

URL : https://journals.openedition.org/cipango/800

DOI : $10.4000 /$ cipango.800

ISSN : 2260-7706

Éditeur

INALCO

\section{Édition imprimée}

Date de publication : 1 janvier 2008

Pagination : 109

ISBN : 978-2-85831-170-5

ISSN : 1164-5857

Référence électronique

"Variations sur le chapitre Suma », Cipango [En ligne], Hors-série | 2008, mis en ligne le 11 juin 2012, consulté le 30 juin 2021. URL : http://journals.openedition.org/cipango/800 ; DOI : https://doi.org/ $10.4000 /$ cipango.800

Ce document a été généré automatiquement le 30 juin 2021.

\section{(c) (7) 8)}

Cipango est mis à disposition selon les termes de la Licence Creative Commons Attribution - Pas d'Utilisation Commerciale 4.0 International. 


\title{
Variations sur le chapitre Suma
}

\author{
Variations on the chapter Suma
}

1 Le Roman du Genji, comme modèle ou hypotexte, a suscité l'écriture d'autres œuvres, a fait naître d'autres systèmes de codification, et l'histoire de la réception de l'œuvre constitue aujourd'hui, sous le nom de juyōshi, le courant principal des études sur le roman $^{1}$. On en trouvera ici quelques exemples centrés sur le chapitre Suma. Michel Vieillard-Baron (http://cipango.revues.org/596) présente un cas d'exploitation originale dans le domaine de la poésie : l'appariement de poèmes extraits du Genji avec des pièces du Roman de Bel habit, œuvre inspirée elle-même par le Genji. Cette "pièce poétique ", réalisée au début du XIII siècle à partir de ces romans, montre un cas intéressant de relecture qui passe par une recontextualisation, et pose en filigrane la question de la place de la poésie dans une œuvre en prose.

2 Sumie Terada (http://cipango.revues.org/597) pour sa part retrace la contribution du roman au développement du renga (poésie en chaîne) dans la période médiévale, et essaie également de relire le chapitre à travers le prisme du renga, sous la problématique du ga (style noble) et du zoku (style bas), notions caractérisant d'une manière générale l'art et la littérature de cette période.

Enfin, Anne Bayard-Sakai (http://cipango.revues.org/600) s'interroge sur le statut d'un texte classique pour un lecteur contemporain à travers l'examen des réécritures en langue japonaise moderne (gendaigo yaku 現代語訳) réalisées par trois romanciers et une poétesse, et pose la question du rapport ambivalent d'appropriation et de distanciation que nous entretenons avec les écrits classiques.

\section{NOTES}

1. Rappelons au passage que chaque année apparaissent plus de trois cents articles de recherche consacrés à ce roman. 


\section{RÉSUMÉS}

Introduction aux articles de M. Vieillard-Baron, S. Terada et A. Bayard-Sakai qui étudient l'histoire de la réception du Genji monogatari dans les domaines de la poésie, du renga, et de la «traduction » en langue moderne d'œuvres anciennes.

Introduction to M. Vieillard-Baron, S. Terada and A. Bayard-Sakai's articles which deal with the reception of the Genji monogatari in poetry, renga and the translation of classic works into modern language.

\section{INDEX}

Thèmes : littérature

キーワード : Genji monogatari 源氏物語, Murasaki Shikibu 紫式部 (v. 973-v. 1014 ou 1025), Heian jidai 平安時代 (794-1185), bungaku 文学

Mots-clés : Dit du Genji, écriture, Genji monogatari, Murasaki Shikibu (v. 973-v. 1014 ou 1025)

Keywords : Genji monogatari, Heian, Literature, Murasaki Shikibu (v. 973-v. 1014 or 1025), Tale of Genji

Index chronologique : Heian 